\title{
A novel 11ß-HSD1 inhibitor improves diabesity and osteoblast differentiation
}

\author{
Ji Seon Park ${ }^{1, *}$, Su Jung Bae, ${ }^{1,2,}$, Sik-Won Choi ${ }^{3}$, You Hwa Son ${ }^{3}$, Sung Bum Park ${ }^{1,4}$ \\ Sang Dal Rhee', Hee Youn Kim ${ }^{1}$, Won Hoon Jung', Seung Kyu Kang', Jin Hee Ahn', \\ Seong Hwan Kim ${ }^{3}$ and Ki Young Kim ${ }^{1,5}$ \\ 'Division of Drug Discovery Research, Korea Research Institute of Chemical Technology, PO Box 107, \\ Yuseong-gu, Daejeon 305-600, Republic of Korea \\ ${ }^{2}$ Division of Life and Pharmaceutical Sciences and Center for Cell Signaling and Drug Discovery Research, \\ College of Pharmacy, Ewha Woman's University, Sedaemoon-gu, Seoul 120-750, Republic of Korea \\ ${ }^{3}$ Laboratory of Translational Therapeutics, Korea Research Institute of Chemical Technology, \\ Pharmacology Research Center, PO Box 107, Yuseong-gu, Daejeon 305-600, Republic of Korea \\ ${ }^{4}$ Department of Toxicology, College of Pharmacy, Chungnam National University, 99 Daehak-ro, \\ Yuseong-gu, Daejeon 305-764, Republic of Korea \\ ${ }^{5}$ Department of Medicinal and Pharmaceutical Chemistry, University of Science and Technology, \\ 217 Gajeong-ro, Yuseong-gu, Daejeon 305-333, Republic of Korea \\ *(J S Park and S J Bae are co-first authors)
}

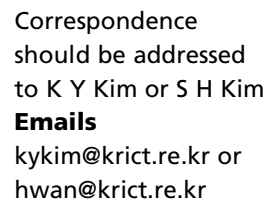

\begin{abstract}
Selective inhibitors of $11 \beta$-hydroxysteroid dehydrogenase type 1 (11 -HSD1) have considerable potential as treatment for osteoporosis as well as metabolic syndrome including type 2 diabetes mellitus. Here, we investigated the anti-diabetic, anti-adipogenic, and antiosteoporotic activity of KR-67500, as a novel selective $11 \beta$-HSD 1 inhibitor. Cellular $11 \beta-H S D 1$ activity was tested based on a homogeneous time-resolved fluorescence method. Oral glucose tolerance test (OGTT) and insulin tolerance test (ITT) levels were measured in diet-induced obese (DIO)-C57BL/6 mice administered KR-67500 (50 mg/kg per day, p.o.) for 28 days and, additionally, its anti-diabetic effect was evaluated by OGTT and ITT. The in vitro anti-adipogenic effect of KR- 67500 was determined by Oil Red O Staining. The in vitro anti-osteoporotic activity of KR-67500 was evaluated using bone morphogenetic protein 2 (BMP2)-induced osteoblast differentiation and receptor activator of nuclear factor- $\mathrm{KB}$ ligand (RANKL)-induced osteoclast differentiation model systems. KR-67500 improved the in vivo glucose tolerance and insulin sensitivity in DIO-C57BL/6 mice. KR-67500 suppressed cortisone-induced differentiation of 3T3L1 cells into adipocytes. KR-67500 enhanced BMP2-induced osteoblastogenesis in C2C12 cells and inhibited RANKL-induced osteoclastogenesis in mouse bone marrow-derived macrophages. KR-67500, a new selective 11 $\beta$-HSD1 inhibitor, may provide a new therapeutic window in the prevention and/or treatment of type 2 diabetes, obesity, and/or osteoporosis.
\end{abstract}

\author{
Key Words \\ - adipose tissue \\ - diabetes II \\ - obesity \\ osteoporosis
}

\section{Introduction}

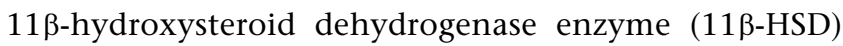
regulates the level of glucocorticoid by converting cortisone (11-dehydrocorticosterone in rodents) to cortisol (corticosterone in rodents), but its dysfunction or an excess of glucocorticoid causes several metabolic disorders (Stewart \& Krozowski 1999, Wang 2005). The relationship
Journal of Molecular Endocrinology (2014) 52, 191-202 
between $11 \beta$-HSD1 and type 2 diabetes mellitus has been demonstrated in mouse genetic models (Masuzaki et al. 2001, Morton et al. 2004). Adipose tissue in 11 $\beta$-HSD1overexpressed mice showed metabolic syndrome-like phenotypes such as central obesity, glucose tolerance, and insulin resistance (Masuzaki et al. 2001, Paterson et al. 2004). By contrast, 11 $\beta$-HSD1-deficient mice showed a reduction in high-fat diet-induced obesity with improved insulin sensitivity and lipid profiles (Kotelevtsev et al. 1997, Morton et al. 2001, 2004).

Furthermore, glucocorticoids are essential for terminal adipogenesis (Hauner et al. 1987) and limit cell proliferation in preadipocytes (Tomlinson et al. 2006). Mature adipocytes express late differentiation genes involved in lipid metabolism and lipid transport, and many of these genes are regulated by glucocorticoids (Wu et al. 1996, Park et al. 2005, 2011, Rosen \& MacDougald 2006).

Additionally, several studies showed that any condition with excess glucocorticoid leads to decreased bone mineral density and increased risk of fracture (Dalle Carbonare et al. 2001, Canalis et al. 2007). Glucocorticoid promotes the expression of receptor activator of nuclear factor- $\kappa \mathrm{B}$ ligand (RANKL) and decreases osteoprotegerin expression in osteoblasts, thus stimulating osteoclastic bone resorption (Hofbauer et al. 1999). Additionally, glucocorticoid suppresses intestinal absorption of calcium and gonadal hormones (Klein et al. 1977).

In a previous study, we developed a series of cyclic sulfamide derivatives with an adamantyl group as $11 \beta$ HSD1 inhibitors (Kim et al. 2012). Among cyclic sulfamide derivatives with an adamantyl group, trans-4-(2-(4-methyl-1,1-dioxido-6-(2,4,6-trichlorophenyl)-1,2,6-thiadiazinan-2-yl)acetamido)adamantane-1-carboxamide (KR-67500) showed potent in vitro activity against human and mouse $11 \beta$-HSD 1 with $\mathrm{IC}_{50}$ values of 1 and $2 \mathrm{nM}$ and exhibited selectivity toward 11 $\beta$-HSD2 (Kim et al. 2012). Furthermore, KR-67500 showed good metabolic stability during incubation of human and mouse liver microsome, weak inhibition of cardiotoxicity, no cytochrome P450 inhibition $(1 \mathrm{~A} 2,2 \mathrm{C} 9,2 \mathrm{C} 19,2 \mathrm{D} 6$, and $3 \mathrm{~A} 4)$, and a $\mathrm{LD}_{50}$ value of over $1000 \mathrm{mg} / \mathrm{kg}$ in ICR mice. Additionally, following oral administration of $10 \mathrm{mg} / \mathrm{kg}$ in rats, KR67500 exhibited systemic clearance of $0.7 \mathrm{l} / \mathrm{h}$ per $\mathrm{kg}$, with terminal half-life of $3.8 \mathrm{~h}$. The absolute oral bioavailability of KR-67500 was $68.8 \%$ in rats. Similarly, following oral administration of $10 \mathrm{mg} / \mathrm{kg}$ in cynomologous monkey, KR-67500 exhibited the maximum concentration of $6.4 \mu \mathrm{g} / \mathrm{ml}$, with terminal half-life of $3.4 \mathrm{~h}$ (Kim et al. 2012).

Here, we have explored whether KR-67500 can improve glucose tolerance and insulin sensitivity in diet-induced obese (DIO)-C57BL/6 mice. Additionally, we accessed the effect of KR-67500 on the cortisoneinduced adipogenesis in 3T3-L1 cells, the bone morphogenetic protein 2 (BMP2)-induced osteoblastogenesis in C2C12 cells, and the RANKL-induced osteoclast differentiation in mouse bone marrow-derived macrophages.

\section{Materials and methods}

\section{Drugs}

KR-67500 compounds were synthesized in the Korea Research Institute of Chemical Technology (Daejon, Korea). Carbenoxolone (CBX) purchased from Amifinecom, Inc. (Petersburg, VA, USA) was used as a reference agent in this study. Cortisone and NADPH were from Sigma-Aldrich.

\section{Animals and drug administration}

All animals were maintained in a room illuminated daily from 0700 to $1900 \mathrm{~h}$ (12 h light:12 h darkness cycle), with controlled temperature $\left(23 \pm 1{ }^{\circ} \mathrm{C}\right)$ and ventilation (10-12 times per hour), and humidity was maintained at $55 \pm 5 \%$. Mice were caged individually and allowed free access to food and tap water in accordance with the NIH Guide for the Care and Use of Laboratory Animals (http://oacu.od.nih.gov/ ac_cbt/guide3.htm). The C57BL/6 mice used in the experiments were purchased from the Orient Bio (Seongnam, Korea). For DIO induction, male C57BL/6 mice were fed with a high-fat diet containing $40 \%(\mathrm{w} / \mathrm{w})$ of total fat $(60 \%$ of total energy from fat, purchased from Diet Research, Inc. (New Brunswick, NJ, USA)) for 12 weeks, starting at 4 weeks of age. The effects of the compounds were tested in DIOC57BL/6 mice, 16-20 weeks in age. The protocol was approved by the Institutional Animal Care and Use Committee (IACUC) of the Korea Research Institute of Chemical Technology, the Ministry of Knowledge Economy, Korea (Permit Number: 2009-7A-09-03).

Animals were weighted regularly to allow accurate dosing with vehicle $(0.5 \%$ carboxymethylcellulose sodium (CMC) in $\mathrm{H}_{2} \mathrm{O}$ ) or KR-67500. KR-67500 was mixed with the vehicles, ground in a mortar, and sonicated to improve the solubility of the compound. Male DIO-C57BL/6 mice were orally gavaged for a week to acclimatize to the vehicle. KR-67500 (50 mg/kg BW) was orally administered twice daily at 0900 and $1700 \mathrm{~h}$ for 4 weeks. After 4 weeks of treatment with the drug, the anti-diabetic effect of KR-67500 was measured using the oral glucose tolerance test (OGTT) and the insulin tolerance test (ITT).

Published by Bioscientifica Ltd. 


\section{OGTT and ITT}

We examined the OGTT and ITT as described previously (Park et al. 2012). The plasma concentration of glucose was measured by colorimetric assay using an automatic biochemical analyzer, the Selectra 2 (Vital Scientific N.V., Spankeren/Dieren, Netherlands). The plasma concentrations of insulin were measured using the insulin assay kit of Shibayagi Co. (Gunma, Japan). HOMA-IR index was calculated from the fasting glucose $(\mathrm{mg} / \mathrm{dl})$ and fasting insulin concentration $(\mu \mathrm{lU} / \mathrm{ml})$ by the equation described elsewhere (fasting insulin $\times$ fasting glucose)/405 (Tachibe et al. 2009).

\section{Cell culture, differentiation, and staining}

Murine 3T3-L1 (CL-173; ATCC, Manassass, VA, USA) preadipocytes were cultured and differentiated into adipocytes as described previously (Park et al. 2012).

Murine bi-potential mesenchymal precursor C2C12 cells (ATCC CRL-1772) were cultured and differentiated into osteoblasts as described in a previous study (Kim \& Kim 2010). Briefly, cells were seeded at a density of $4 \times 10^{3}$ or $1.5 \times 10^{5}$ cells/well in 96-well plate and six-well culture plates respectively. After 1-day of incubation, the osteoblastogenesis was triggered by the medium containing 5\% FBS and rhBMP-2 (50 ng/ml; R\&D Systems, Minneapolis, MN, USA). An Alkaline Phosphatase (ALP) Kit (SigmaAldrich) was used to visualize cellular ALP expression.

BMMs-based osteoclast differentiation and TRAP activity assay were carried out as described in a previous study (Choi et al. 2013).

\section{Lipid accumulation assay}

The cellular lipid content was assessed by Oil Red O staining (Sigma-Aldrich). After 7 days, cells were washed and fixed in $1 \%$ paraformaldehyde for $1 \mathrm{~h}$, stained with Oil Red O working solution, and incubated for another $4 \mathrm{~h}$ at $37^{\circ} \mathrm{C}$. After being washed three times with PBS, the cells were photographed using a light microscope (Olympus, Tokyo, Japan).

\section{Real-time quantitative PCR analysis}

We examined the genes expression as described previously (Park et al. 2011). Expression studies were carried out using gene-specific primers for mouse peroxisome proliferator-activated receptor $\gamma$ (Pparg2), glycerol-3-phosphate dehydrogenase (Gpd1), fatty acid binding protein 4 (Fabp4), glucose transporter 4 (Slc2a4), Hsd11b1, Alppl2, Bmp4, Acp5, Fos, nuclear factor of activated T cells c1
(Nfatc1), Ctsk, and dendrite cell-specific transmembrane protein (Dcstamp). All primers were designed using primer 3 software (http://bioinfo.ut.ee/primer3-0.4.0/) and their sequences from $5^{\prime}$ to $3^{\prime}$ are shown in Table 1 . The relative abundance of mRNA was calculated after normalization to glyceraldehyde-3-phosphate dehydrogenase (Gapdh).

\section{In vitro $11 \beta$-HSD1 enzyme activity assay}

We examined the cellular 11 -HSD1 enzyme activity as described previously (Cho et al. 2009). Differentiated C2C12 cells for 3 days in the presence of BMP2 $(50 \mathrm{ng} / \mathrm{ml})$ and 3T3-L1 adipocytes were seeded at $2 \times 10^{4}$ cells/well or $5 \times 10^{4}$ cells/well onto 96 - or 24 -well plates and incubated in a medium containing $160 \mathrm{nM}$ cortisone in the presence or absence of compounds $24 \mathrm{~h}$ (3T3-L1 cells) and $48 \mathrm{~h}$ (C2C12 cells). Small aliquots $(10 \mu \mathrm{l})$ of the reaction mixtures were removed and subjected to homogeneous time-resolved fluorescence cortisol assay in accordance with the manufacturer's instructions (Nihon Schering, Tokyo, Japan). The $\mathrm{IC}_{50}$ values of the compounds were determined from concentration-dependent inhibition curves by GraphPad Prism software (GraphPad Software, Inc., La Jolla, CA, USA). CBX was used as the reference compounds.

\section{Ex vivo $11 \beta$-HSD1 enzyme activity assay}

We examined the ex vivo 11 $\beta$-HSD1 enzyme activity as described previously (Park et al. 2012). Male C57BL/6 mice, 12 weeks old, were orally gavaged with vehicle $(0.5 \%$ CMC/0.1\% Tween 80 in $\mathrm{H}_{2} \mathrm{O}$ ) or KR-67500 at 0.5, 1, 5, and $10 \mathrm{mg} / \mathrm{kg}$ and killed 2 or $6 \mathrm{~h}(10 \mathrm{mg} / \mathrm{kg})$ after dose $(n=4$ per group).

Table 1 Primer sequences for various mouse genes for real-time PCR. Primers were designed using Primer3 software (http://bioinfo.ut.ee/primer3-0.4.0/)

\begin{tabular}{|c|c|c|}
\hline Gene & Forward & Reverse \\
\hline Pparg & ccctggcaaagcatttgtat & gaaactggcacccttgaaaa \\
\hline Gpd1 & agagatgctcgccacagaat & aaagggtctctggggtctgt \\
\hline Fabp4 & catcagcgtaaatggggatt & tcgactttccatcccacttc \\
\hline S/c2a4 & ctccttctatttgccgtcctc & ctgttttgcccctcagtcatt \\
\hline$H s d 11 b 1$ & gggataattgacgccctagc & tgaggcaggactgttctaag \\
\hline Alpp/2 & atgggcgtctccacagraac & tcacccgagtggtagrcaca \\
\hline Bmp4 & cctggtaaccgaatgctgat & agccggtaaagatccctcat \\
\hline Fos & ccagtcaagagcatcagcaa & aagtagtgcagcccggagta \\
\hline Nfatc1 & gggtcagtgtgaccgaagat & ggaagtcagaagtgggtgga \\
\hline Dcstamp & ccaaggagtcgtccatgatt & ggctgctttgatcgtttctc \\
\hline $\begin{array}{l}\text { Ctsk } \\
\text { Gapdh }\end{array}$ & $\begin{array}{l}\text { ggccaactcaagaagaaaac } \\
\text { aactttggcattgtggaagg }\end{array}$ & $\begin{array}{l}\text { gtgcttgcttcccttctgg } \\
\text { cacattgggggtaggaacac }\end{array}$ \\
\hline
\end{tabular}

Published by Bioscientifica Ltd http://jme.endocrinology-journals.org DOI: 10.1530/JME-13-0177
(C) 2014 Society for Endocrinology Printed in Great Britain 


\section{Statistical analysis}

All data are expressed as mean \pm s.e.m. Statistical significance was determined by one-way ANOVA followed by a Turkey's multiple-comparison test. $P<0.05$ was considered to be statistically significant.

\section{Results}

\section{Effect of KR-67500 on glucose tolerance and insulin sensitivity in DIO-C57BL/6 mice}

We evaluated whether the inhibitory activity of KR-67500 on 11 $\beta$-HSD1 ameliorated glucose tolerance and insulin resistance in DIO-C57BL/6 mice after treatment with KR-67500 (50 mg/kg per day, orally for 28 days). Oral treatment with KR-67500 resulted in increased glucose clearance and plasma glucose levels, as determined by the area under the glucose concentration curve (AUC), were significantly reduced by $10.6 \%$ compared with the vehicle by administration of KR-67500 (Fig. 1A). Using the same mouse model, we measured the insulin sensitivity by KR-67500 using ITT (Fig. 1B). The mean AUC of the KR-67500-treated mice was also significantly $(P<0.05)$ lower than that of the vehicle-treated mice. Furthermore, the plasma fasting insulin concentration and HOMA-IR index of the KR-67500-treated mice was lower than that of the vehicle-treated DIO-C57BL/6 mice (Fig. $1 \mathrm{C}$ and D). In this manner, treatment of KR-67500 improved plasma lipid profiles such as triglyceride (TG) and HDL- and LDL-cholesterol in the vehicle-treated DIO-C57BL/6 mice after 28 days (Table 2 ).

Additionally, KR-67500 inhibited the $11 \beta$-HSD1 enzyme activity in liver, inguinal fat, and reproductive fat of DIO-C57BL/6 mice (Fig. 1E).

\section{Effect of KR-67500 on cortisone-induced adipogenesis in 3T3-L1 cells}

Adipocytes with $1 \mu \mathrm{M}$ cortisone showed increased lipid accumulation when assessed after 7 days (data not shown). This effect was removed by co-incubation with KR-67500 in a concentration-dependent manner (Fig. 2A) without apparent cytotoxicity (data not shown).

Furthermore, we examined whether the mRNA expression of adipogenesis-specific genes is inhibited by KR-67500. On day 7, real-time PCR was performed to analyze the mRNA levels of key transcription factors in adipogenesis such as Pparg, Gpd1, Fabp4, and Slc2a4. As shown in Fig. 2B, KR-67500 significantly downregulated the overexpression of all these genes by $1 \mu \mathrm{M}$ cortisone in a concentration-dependent manner.

In Fig. 3A, KR-67500 inhibited the $11 \beta$-HSD1 activity of 3T3-L1 adipocytes in a concentration-dependent manner, and the $\mathrm{IC}_{50}$ value of $\mathrm{KR}-67500$ was $4.3 \mathrm{nM}$. The $\mathrm{IC}_{50}$ value of $\mathrm{CBX}$ was $170 \mathrm{nM}$. Treatment of KR-67500 also inhibited the induction of $11 \beta$-HSD1 expression by cortisone in 3T3-L1 adipocytes. In this manner, KR-67500 was administered to lean C57BL/6 mice in a single $0.5,1,5$, and $10 \mathrm{mg} / \mathrm{kg}$ oral dose, and after $2 \mathrm{~h}$, the inhibition of $11 \beta$-HSD1 enzyme activity of inguinal fat was measured ex vivo by incubating fat in media containing cortisone and NADPH. KR-67500 inhibited in a concentration-dependent manner, with $>50 \%$ inhibition at $0.5 \mathrm{mg} / \mathrm{kg}$ (Fig. 3B). Furthermore, treatment of $10 \mathrm{mg} / \mathrm{kg}$ KR-67500 also significantly inhibited the $11 \beta$-HSD1 enzyme activity at 2 and $6 \mathrm{~h}$ in inguinal and reproductive fats (Fig. 3C).

\section{Effect of KR-67500 on osteoblast differentiation in C2C12 cells}

In C2C12 cells, KR-67500 dose-dependently enhanced the BMP2-induced expression of ALP, a biomarker of osteoblastogenesis (Fig. 4A) without apparent cytotoxicity (data not shown). Osteogenic activity of KR-67500 was stronger than that of CBX at $10 \mu \mathrm{M}$. Neither KR-67500 nor CBX exhibited the osteogenic activity in the absence of BMP2. The osteogenic activity of KR-67500 was confirmed by real-time PCR analysis (Fig. 4B); the BMP2-induced mRNA expression levels of Alppl2 and Bmp4 were significantly enhanced by the addition of KR-67500.

Furthermore, on differentiation day 3, the cellular oxo-reductase activity of $11 \beta$-HSD1 in C2C12 cells was significantly inhibited by KR-67500 with $>50 \%$ inhibition at $0.001 \mu \mathrm{M}$ (Fig. 5A). An inhibitory effect of CBX on the activity of $11 \beta$-HSD1 was also observed, but it was weaker than that of KR-67500. The mRNA expression of $11 \beta$-HSD1 was significantly inhibited by BMP2, and its inhibition was stronger in cells treated with BMP-2 and KR-67500 (Fig. 5B). Thus, these results suggested that KR-67500 could enhance the BMP2-induced osteoblast differentiation with the inhibition of $11 \beta$-HSD1 enzyme expression and activity.

\section{Effect of KR-67500 on osteoclast differentiation in BMMs}

In the BMM-based osteoclastogenesis model, the effect of KR-67500 on the osteoclast differentiation was evaluated by staining TRAP and measuring its activity. TRAP is a

Published by Bioscientifica Ltd. 

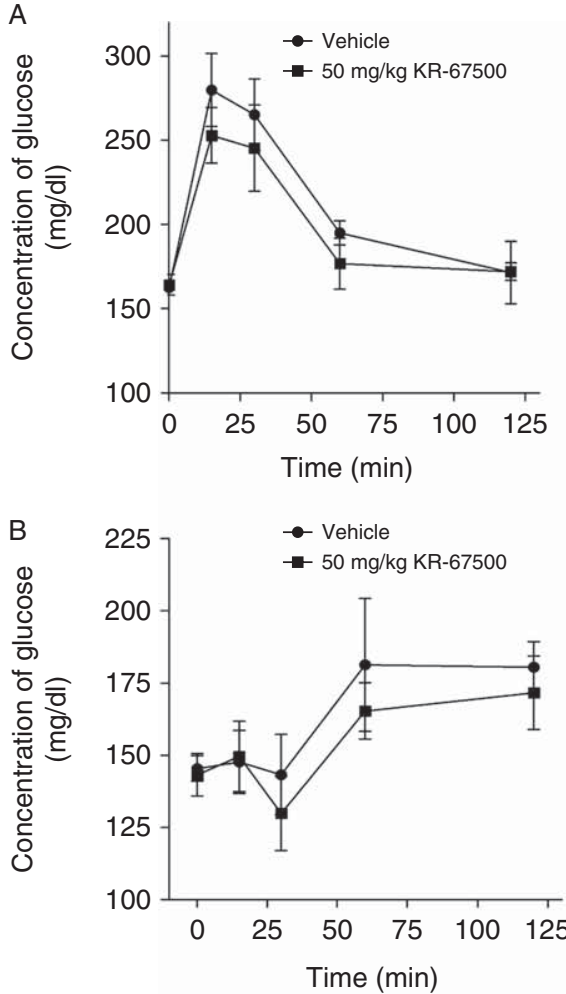

C

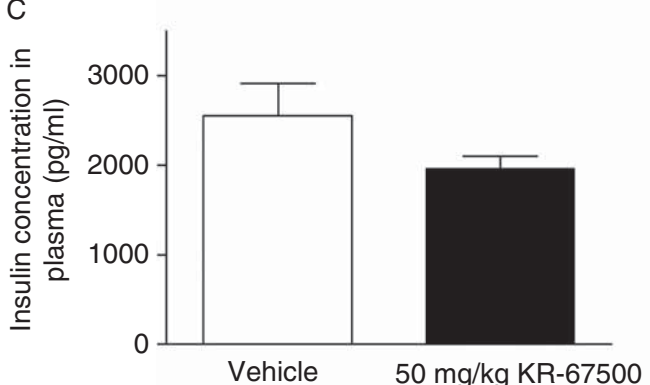

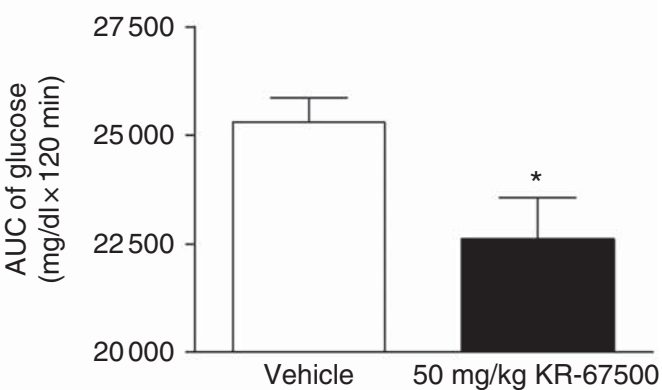

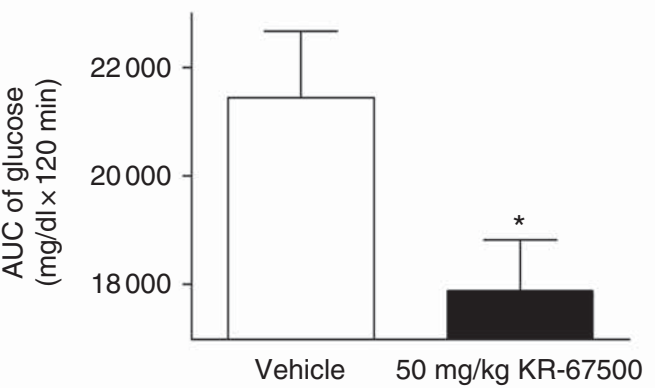

D

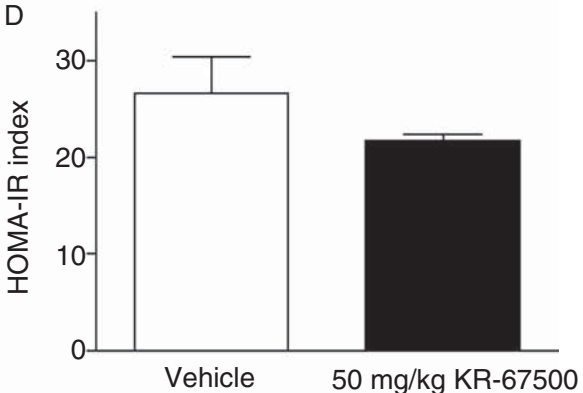

$\mathrm{E}$

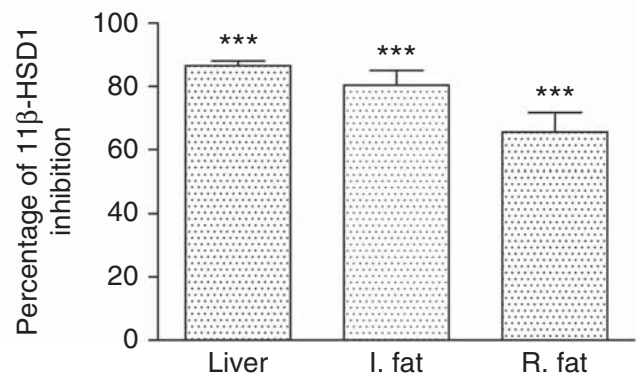

Figure 1

Anti-diabetic effect of KR-67500 on glucose tolerance and insulin sensitivity in DIO-C57BL/6 mice. DIO-C57BL/6 mice were administered with vehicle and KR-67500 (50 mg/kg BW) daily by oral gavage for 28 days. (A) The oral glucose tolerance test. (B) The insulin tolerance test. (closed circle) DIO-C57BL/6 - vehicle, (closed square) DIO-C57BL/6 - KR-67500. (C) Plasma fasting insulin concentration. (D) HOMA-IR index analysis. (E) Ex vivo
$11 \beta$-HSD1 enzyme activity in liver, inguinal fat, and reproductive fat of KR-67500 treated DIO-C57BL/6 mice. The ex vivo assay was carried out at $16 \mathrm{~h}$ after the last administration in the in vivo DIO-C57BL/6 mice study. Results are expressed as mean \pm S.E.M. for $n=6-9$ mice per group. ${ }^{*} P<0.05$, $* * * P<0.001$ vs DIO-C57BL6 vehicle group. $\begin{array}{lr}\text { http://jme.endocrinology-journals.org } & \text { ( } 2014 \text { Society for Endocrinology } \\ \text { DOI: } 10.1530 / J M E-13-0177 & \text { Printed in Great Britain }\end{array}$ 
Table 2 Metabolic parameters of mice with KR-67500. Values are mean \pm s.E.M.; $n=6-8 /$ group

\begin{tabular}{|c|c|c|}
\hline & DIO-vehicle & KR-67500 $(50 \mathrm{mg} / \mathrm{kg})$ \\
\hline Cholesterol (mg/dl) & $241.0 \pm 12.9$ & $259.4 \pm 10.7$ \\
\hline $\mathrm{TG}(\mathrm{mg} / \mathrm{dl})$ & $86.2+9.4$ & $60.9+4.5 *$ \\
\hline HDL (mg/dl) & $163.3 \pm 6.4$ & $188.8 \pm 7.7$ * \\
\hline FFA $(\mu \mathrm{Eq} / \mathrm{l})$ & $1866.7 \pm 147.8$ & $1856.7 \pm 80.2$ \\
\hline LDL (mg/dl) & $81.9 \pm 5.7$ & $65.6 \pm 3.4^{*}$ \\
\hline
\end{tabular}

TG, triglyceride; FFA, free fatty acid. ${ }^{*} P<0.05$ vs DIO-vehicle group.

well-known biomarker of osteoclastogenesis. As shown in Fig. 6A, BMMs differentiated into TRAP-positive multinucleated osteoclasts in response to M-CSF and RANKL, but KR-67500 dose-dependently inhibited the formation of TRAP-positive multinucleated osteoclasts without apparent cytotoxicity (data not shown). CBX did not exhibit any anti-osteoclastogenic action.
TRAP activity assay and the real-time PCR analysis revealed that KR-67500 dose-dependently inhibited the TRAP activity (Fig. 6B) and significantly attenuated the RANKL-induced mRNA expression of genes related to fusion (Fos, Nfatc1, and Dcstamp) and function (Ctsk) of osteoclasts (Fig. 6C). However, the mRNA expression of 11ß-HSD1-related genes (Hsd11b1, gr, and H6pd) were not changed by KR-67500 in the process of osteoclastogenesis (data not shown).

\section{Discussion}

Numerous rodent studies have demonstrated the potential use of $11 \beta$-HSD1 inhibitors as treatment for the components of metabolic syndrome, and limited clinical data on humans have shown 11ß-HSD1 inhibition to improve glucose levels, insulin sensitivity, and lipid profiles.

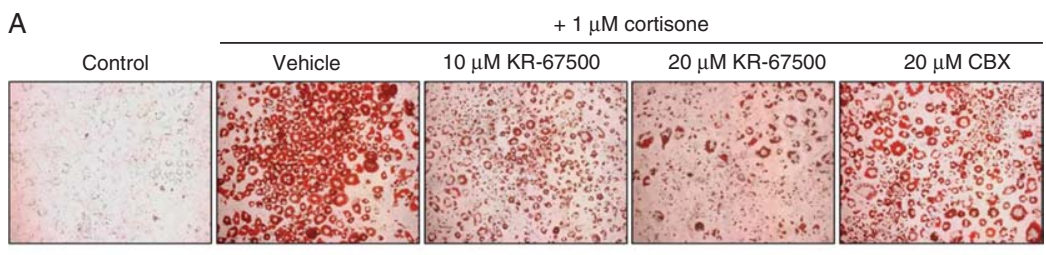

$(\times 200)$
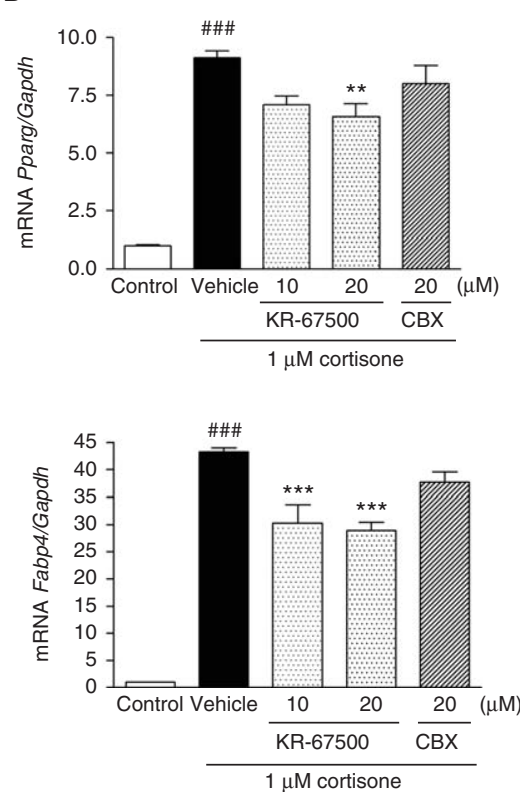
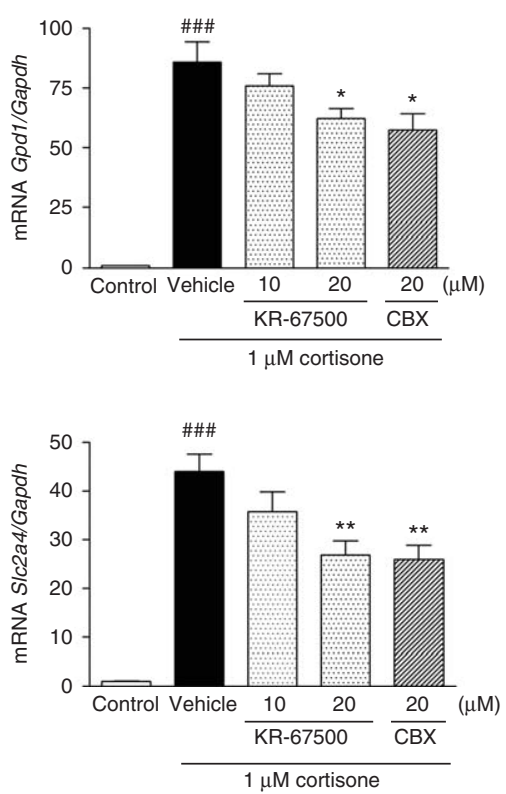

compounds for 2 days, and the cells were then cultured for 1 day in culture medium. Values are mean \pm s.E.M. of data from two separate experiments with three replicates. ${ }^{\# \# \#} P<0.001$ vs control group; ${ }^{*} P<0.05, * * P<0.01$, $* * * P<0.001$ vs vehicle group. A full colour version of this figure is available via http://dx.doi.org/10.1530/JME-13-0177. http://jme.endocrinology-journals.org DOI: 10.1530/JME-13-0177
(C) 2014 Society for Endocrinology Printed in Great Britain 

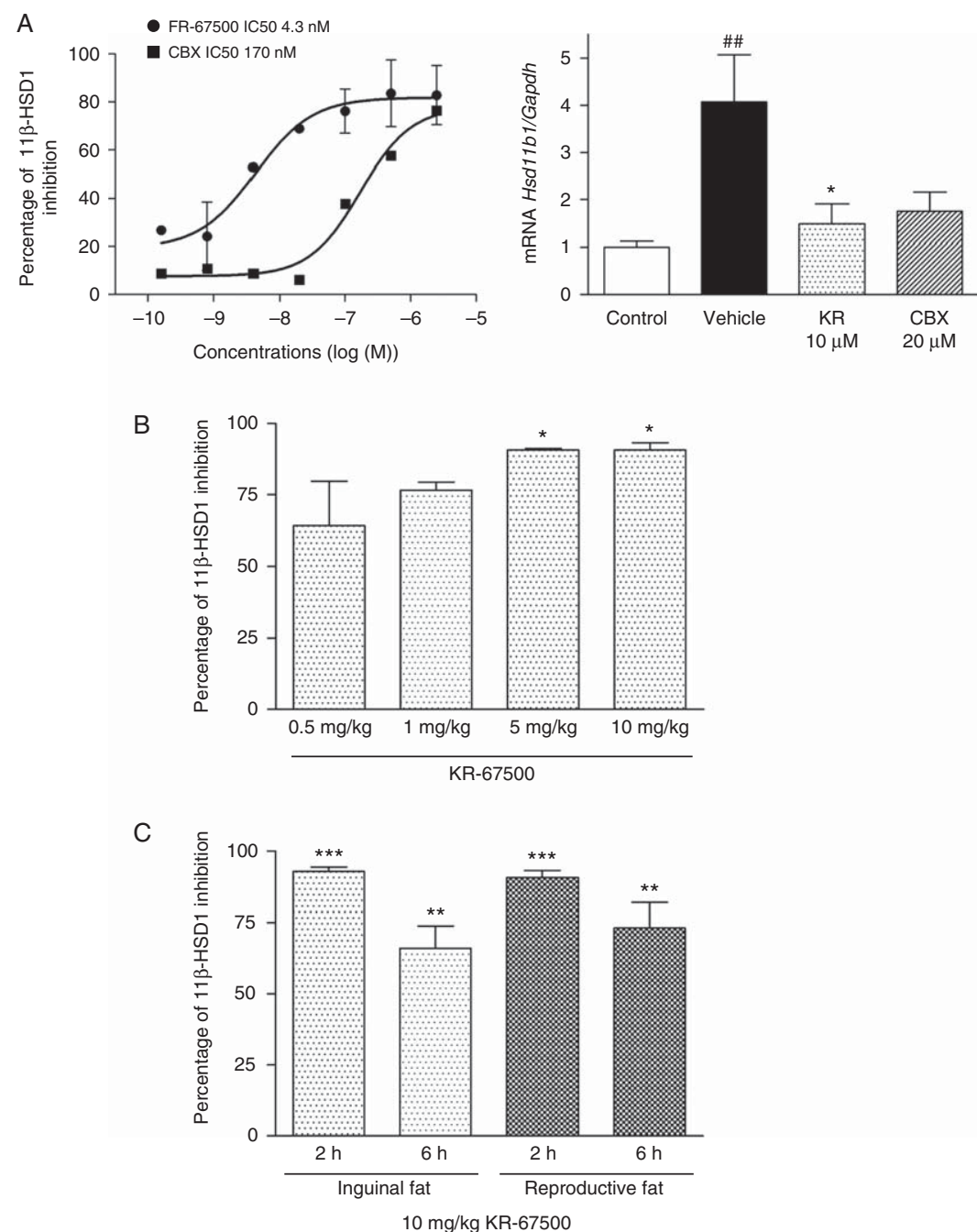

\section{Figure 3}

The $11 \beta-H S D 1$ enzyme activity of KR-67500 in mouse 3T3-L1 adipocytes (A) and in the inguinal or reproductive fat of C57BL/6 mice (B). (A) In vitro $11 \beta$ HSD1 enzyme inhibitory activity and expression of KR-67500 in adipocytes. The $11 \beta$-HSD1 expression was determined by real-time PCR. Values are mean \pm S.E.M. of data from two separate experiments with three replicates. $\# \# P<0.01$ vs preadipocyte group; ${ }^{*} P<0.05$ vs cortisone-treated group. (B) Ex vivo concentration dependency assay on $11 \beta$-HSD1 enzyme inhibitory

In this study, we have explored whether a novel 11 $\beta$-HSD1 inhibitor, KR-67500, can improve glucose tolerance and insulin sensitivity in DIO-C57BL/6 mice and additionally prevent the cortisone-induced adipogenesis, the BMP2induced $\mathrm{C} 2 \mathrm{C} 12$ osteogenesis, and the RANKL-induced osteoclast differentiation via the inhibition of 11ß-HSD1 enzyme activity.

The relationships between $11 \beta$-HSD1 and type 2 diabetes have been demonstrated in mouse genetic models. The 11 $\beta$-HSD1-overexpressing transgenic mice in adipose tissues showed metabolic syndrome-like phenotypes such activity of KR-67500. Male C57BL/6 mice were orally gavaged with vehicle or KR-67500 and killed $2 \mathrm{~h}$ post dose. (C) Ex vivo time-dependency assay on $11 \beta$-HSD1 inhibitory activity of KR-67500. Male lean mice were orally gavaged with vehicle or $10 \mathrm{mg} / \mathrm{kg}$ KR-67500 and killed 2 and $6 \mathrm{~h}$ post dose. Results are expressed as mean \pm S.E.M. for $n=4$ mice per group. ${ }^{*} P<0.05$, $* * P<0.01, * * * P<0.001$ vs C57BL/6 vehicle group.

as central obesity, glucose intolerance, and insulin resistance (Masuzaki et al. 2001), but those tissues from $H s d 11 b 1$ knock-out mice showed a reduction in high-fat dietinduced obesity with improved insulin sensitivity and lipid profiles (Morton et al. 2004). Furthermore, Rosenstock et al. (2010) published the results of a 12-week efficacy study evaluating INCB13739 (Incyte Corporation, Wilmington, DE, USA), a potent selective $11 \beta$-HSD1 inhibitor, in patients with type 2 diabetes mellitus who were failing metformin monotherapy. In this study, oral treatment with KR-67500, a novel selective 11ß-HSD1 inhibitor,

Published by Bioscientifica Ltd. 
A
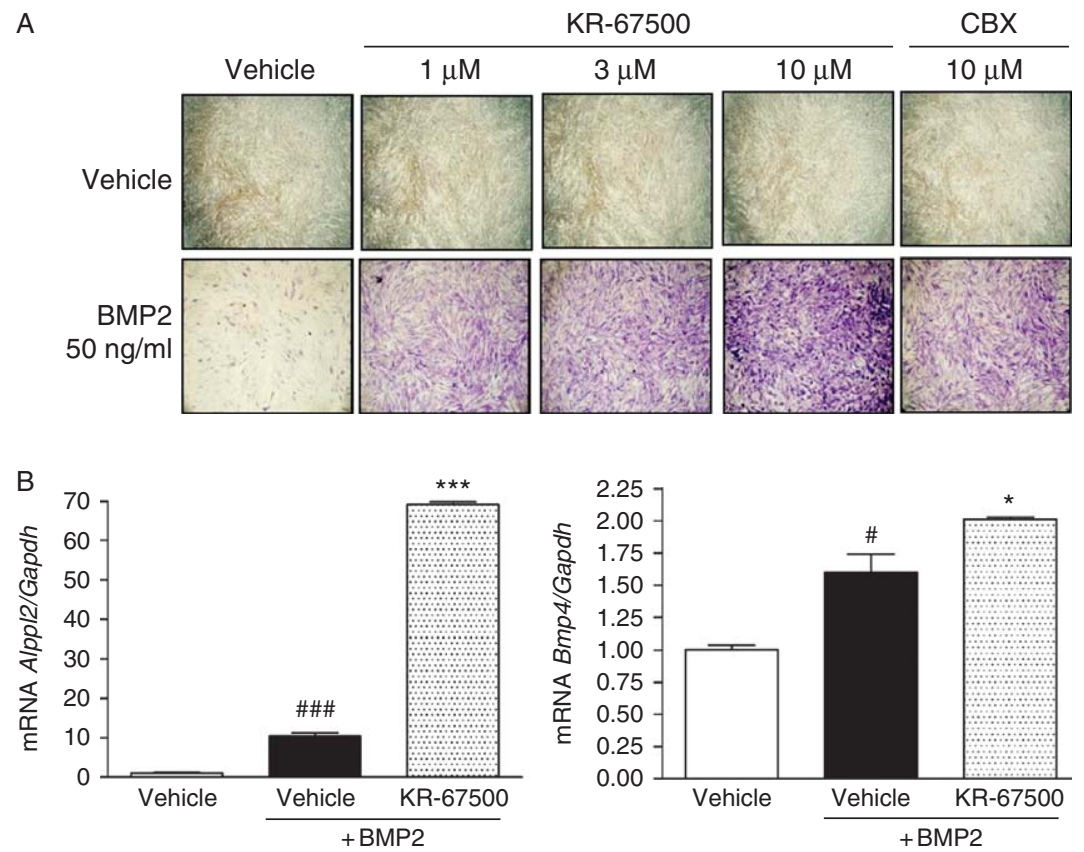

\section{Figure 4}

Osteogenic activity of KR-67500. Osteogenic activity of KR-67500 was evaluated by visualizing the expression of ALP (A) and measuring the mRNA expressions of ALP and osteogenic BMPs in C2C12 cells (B). Real-time PCR and ALP staining were carried out on differentiation days 3 and 6 respectively. Cells were incubated with vehicle (DMSO)

exhibited significantly improved glucose tolerance and insulin sensitivity, as determined through several assays including an OGTT, ITT, plasma fasting insulin concentration assay, and HOMA-IR index analysis in DIOC57BL/6 mice. In this manner, treatment of KR-67500 improved plasma lipid profiles such as TG and HDL- and LDL-cholesterol in the vehicle-treated DIO-C57BL/6 mice after 28 days. Additionally, KR-67500 significantly inhibited $11 \beta$-HSD1 activity in the liver and fat of DIO-C57BL/6 mice. Considering these results, it is suggested that the improvement of glucose tolerance and insulin sensitivity by KR-67500 in diabetic mice can be ascribed to the inhibition of $11 \beta$-HSD1 enzyme activity in the liver and fat.

Recent investigations showed that $11 \beta$-HSD 1 inhibitors prevented adipogenesis with beneficial application to the treatment of obesity in diabetic patients (Bujalska et al. 2008). Mature adipocytes express late differentiation genes involved in lipid metabolism and lipid transport, including Gpd1 and Fabp4 (Hotamisligil et al. 1996), and many of these genes are regulated by glucocorticoids (Wu et al. 1996, Rosen \& MacDougald 2006). PPARG was shown to play an important role in adipocyte differentiation, glucose homeostasis, and or KR-67500 $(10 \mu \mathrm{M})$ in the presence of BMP2 for mRNA analysis. ${ }^{\#} P<0.05$, ${ }^{\# \#} P<0.001$ vs control group; ${ }^{*} P<0.05$, $* * * P<0.001$ vs BMP2-treated group. A full colour version of this figure is available via http://dx.doi.org/10.1530/JME-13-0177.

insulin signaling (Kersten et al. 2000). Moreover, glucose transporter, type 4 (GLUT4) is selectively expressed in insulin-sensitive tissues such as muscle and adipose cells (Bryant et al. 2002) and impairment of glucose uptake by adipose and muscle tissues in obesity is associated with the reduction of cellular GLUT4 content (Sato et al. 1997), while a loss of body weight from diet therapy greatly improves abnormal glucose homeostasis (Wing et al. 1994). In our results, preadipocytes with $1 \mu \mathrm{M}$ cortisone showed increased lipid accumulation when assessed after 7 days and these effects were eliminated by co-incubation with KR-67500. In line with this, the mRNA expression of adipogenesis-specific genes was inhibited by KR-67500; the mRNA levels of Pparg, Gpd1, Fabp4, and Slc2a4 was increased by cortisone; and these inductions were inhibited by KR-67500. Moreover, KR-67500 inhibited Hsd11b1 mRNA expression and enzyme activity in adipocytes. Furthermore, in ex vivo 11ß-HSD1 activity assay of inguinal fats of C57BL/6 mice, KR-67500 inhibited in a concentration-dependent manner, with $>50 \%$ inhibition at $0.5 \mathrm{mg} / \mathrm{kg}$. Treatment of $10 \mathrm{mg} / \mathrm{kg}$ KR-67500 also significantly inhibited the $11 \beta$-HSD1 enzyme activity at 2 and $6 \mathrm{~h}$ in inguinal and reproductive

Published by Bioscientifica Ltd. 


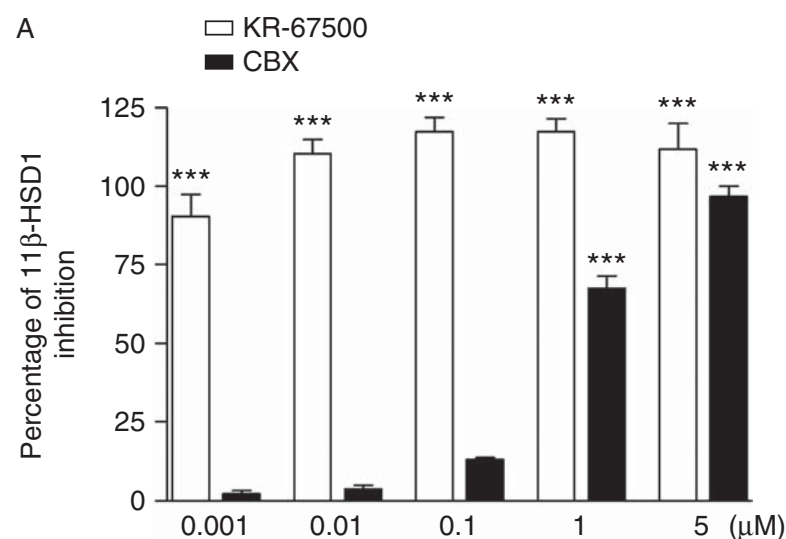

B

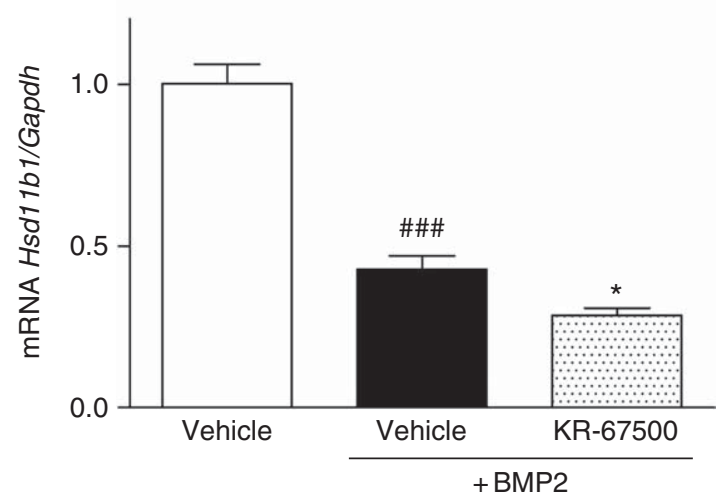

Figure 5

Inhibitory effect of KR-67500 on the activity (A) and the expression of $11 \beta$-HSD1 in differentiated C2C12 cells (B). (A) Mouse-differentiated $\mathrm{C} 2 \mathrm{C} 12$ cells were seeded at $2 \times 10^{4}$ cells/well onto 96 -well plates and incubated in a medium containing $160 \mathrm{nM}$ cortisone in the presence or absence of compounds for $48 \mathrm{~h}$ at $37^{\circ} \mathrm{C}$. Results are expressed as mean \pm S.E.M. of triplicate experiments. ${ }^{* *} P<0.001$ vs cortisone-treated group. (B) Effect of KR-67500 on mRNA 11 $\beta$-HSD1 expression in BMP2-treated C2C12 cells. The mRNA $11 \beta$-HSD1 expression was determined by real-time $P C R$. Values are mean \pm s.E.M. of data from two separate experiments with three replicates. ${ }^{\# \#} P<0.001$ vs control group; ${ }^{*} P<0.05$ vs BMP2-treated group.

fats. Similarly, following oral administration of $10 \mathrm{mg} / \mathrm{kg}$ in cynomologous monkey, KR-67500 significantly inhibited the $11 \beta$-HSD1 enzyme activity with $>80 \%$ in inguinal and reproductive fats after $2 \mathrm{~h}$ treatment. These results provide evidence to support our hypothesis that KR-67500 can inhibit cortisone-induced adipogenesis in 3T3-L1 adipocytes via inhibition of $11 \beta-H S D 1$ expression and enzyme activity.

The functional involvement of $11 \beta$-HSD1 in bone formation has been reported in several studies. Importantly, osteoblastic $11 \beta$-HSD1 activity increased with age and glucocorticoid exposure, and the activation of glucocorticoids at an autocrine level within bone is likely to play a critical role in the age-related decrease in bone formation and increased risk of glucocorticoidinduced osteoporosis (Cooper et al. 2002). In this study, we found the enhancing effects of KR-67500 and CBX on the BMP2-induced osteoblast differentiation with the induction of ALP, but the osteogenic activity of CBX was less marked than that of KR-67500. Neither KR-67500 nor $\mathrm{CBX}$ exhibited the osteogenic activity in the absence of BMP2, suggesting the BMP2-dependent osteogenic action of both. Also, KR-67500 enhanced the BMP2-induced expression of another osteogenic BMP4 (Yamaguchi et al. 1996, Li et al. 2005). Furthermore, the inhibitory effect of KR-67500 on the activity of $11 \beta-H S D 1$ clarified that its osteogenic action could be due to its potential to interrupt the activity of $11 \beta$-HSD1. KR-67500 also significantly enhanced the BMP2-mediated decrease in Hsd11b1 mRNA expression. These data were consistent with the results of a previous study, which showed that in human bone tissue, 11 $\beta$-HSD1 enzyme activity is predominant (Cooper et al. 2000), but its mRNA expression and activity are low in differentiating osteoblasts (Eijken et al. 2005).

The immunohistochemistry and in situ hybridization

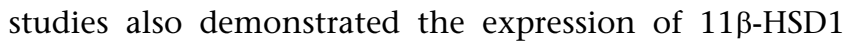
isozymes in osteoclasts (Cooper et al. 2000). In a human study, ingestion of CBX resulted in a significant decrease in the bone resorption markers, suggesting that the pharmacologic inhibition of $11 \beta$-HSD1 activity could decrease the process of bone resorption (Cooper et al. 2000), but as yet there is not enough experimental evidence to explain the functional involvement of $11 \beta$ HSD1. In this study, we found the anti-osteoclastogenic activity of KR-67500, but not that of CBX. Considering that there was no activity of $11 \beta-H S D 1$ in BMMs, the antiosteoclastogenic action of KR-67500 might not be due to its inhibitory activity to $11 \beta$-HSD1. Instead, real-time PCR analysis suggested that the anti-oseteoclastogenic activity of KR-67500 might be due to its potential to downregulate the expression of genes related to fusion (Fos, Nfatc1, and Dcstamp) and function (cathepsin K) of osteoclasts (Wang et al. 1992, Ishikawa et al. 2001, Takayanagi et al. 2002, Kim et al. 2008). The possibility that KR-67500 can target another molecule in BMM is still open.

In summary, KR-67500, a novel 11 $\beta-H S D 1$ inhibitor, exhibits the anti-diabetic and anti-adipogenic activities. Also, KR-67500 enhances the oseteoblastogenesis and inhibits the osteoclastogenesis. A novel selective $11 \beta$-HSD1 inhibitor may provide a new therapeutic window in the prevention and treatment of type 2 diabetes patients with obesity and osteoporosis.

Published by Bioscientifica Ltd. 
$+5 \mathrm{ng} / \mathrm{ml}$ RANKL

A $+30 \mathrm{ng} / \mathrm{ml} \mathrm{M}-\mathrm{CSF}$

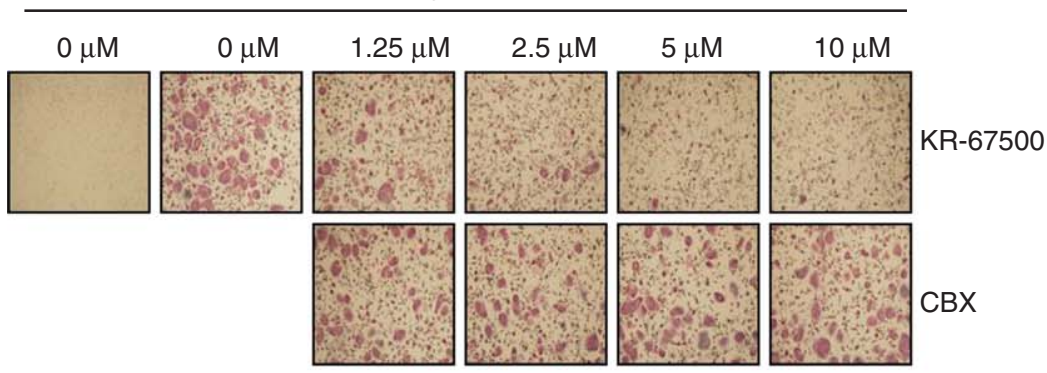

B KR-67500

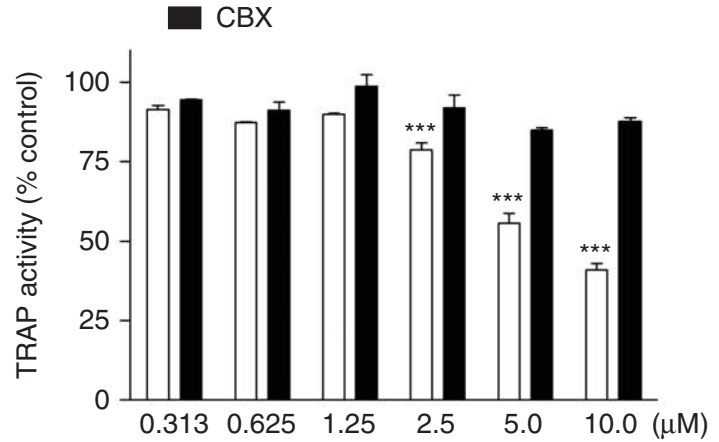

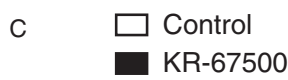

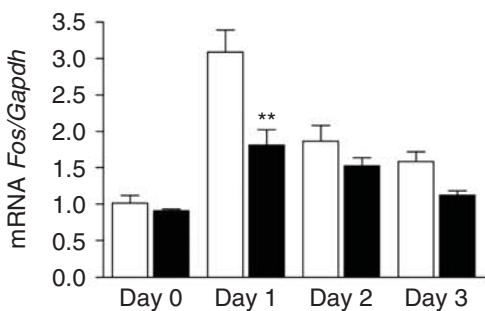

Control

KR-67500

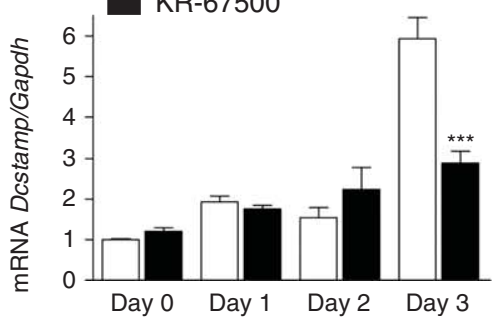

Figure 6

Anti-osteoclastogenic activity of KR-67500. BMM cells were cultured for 4 days in the presence of RANKL $(5 \mathrm{ng} / \mathrm{ml})$ and M-CSF $(30 \mathrm{ng} / \mathrm{ml})$ with KR67500 or CBX. Multinucleated osteoclasts were visualized to red-colored giant cells by TRAP staining (A) and their activity was also measured (B). (C) Effect of KR-67500 on osteoclastogenesis-related gene expressions.

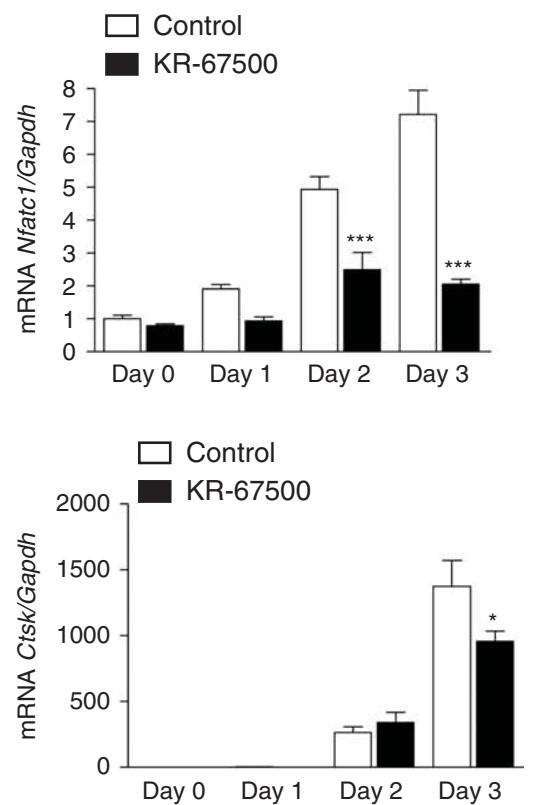

After treating the vehicle (DMSO) or KR-67500 $(5 \mu \mathrm{M})$ for $1 \mathrm{~h}$, BMMs were treated with RANKL $(5 \mathrm{ng} / \mathrm{ml})$ for the indicated number of days and then mRNA expression levels were analyzed by real-time PCR. ${ }^{*} P<0.05$, $* * P<0.01, * * * P<0.001$ vs control group. A full colour version of this figure is available via http://dx.doi.org/10.1530/JME-13-0177.

Published by Bioscientifica Ltd. 


\section{Declaration of interest}

The authors declare that there is no conflict of interest that could be perceived as prejudicing the impartiality of the research reported.

\section{Funding}

This research was supported by the Center for Biological Modulators of the 21st Century Frontier R\&D Program, the Ministry of Education, Science and Technology, and the project of the Korea Research Institute of Chemical Technology, the Ministry of Knowledge Economy, Korea.

\section{References}

Bryant NJ, Govers R \& James DE 2002 Regulated transport of the glucose transporter GLUT4. Nature Reviews. Molecular Cell Biology 3 267-277. (doi:10.1038/nrm782)

Bujalska IJ, Gathercole LL, Tomlinson JW, Darimont C, Ermolieff J, Fanjul AN, Rejto PA \& Stewart PM 2008 A novel selective 11 $\beta$-hydroxysteroid dehydrogenase type 1 inhibitor prevents human adipogenesis. Journal of Endocrinology 197 297-307. (doi:10.1677/JOE-08-0050)

Canalis E, Mazziotti G, Giustina A \& Bilezikian JP 2007 Glucocorticoidinduced osteoporosis: pathophysiology and therapy. Osteoporosis International 18 1319-1328. (doi:10.1007/s00198-007-0394-0)

Cho YS, Kim CH \& Cheon HG 2009 Cell-based assay for screening $11 \beta$-hydroxysteroid dehydrogenase 1 inhibitors. Analytical Biochemistry 392 110-116. (doi:10.1016/j.ab.2009.04.038)

Choi SW, Moon SH, Yang HJ, Kwon DY, Son YJ, Yu R, Kim YS, Kim SI, Chae EJ, Park SJ et al. 2013 Antiresorptive activity of bacillus-fermented antler extracts: inhibition of osteoclast differentiation. Evidence-Based Complementary and Alternative Medicine: eCAM 2013748687.

Cooper MS, Walker EA, Bland R, Fraser WD, Hewison M \& Stewart PM 2000 Expression and functional consequences of $11 \beta$-hydroxysteroid dehydrogenase activity in human bone. Bone 27 375-381. (doi:10.1016/S8756-3282(00)00344-6)

Cooper MS, Rabbitt EH, Goddard PE, Bartlett WA, Hewison M \& Stewart PM

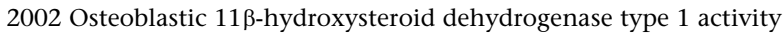
increases with age and glucocorticoid exposure. Journal of Bone and Mineral Research 17 979-986. (doi:10.1359/jbmr.2002.17.6.979)

Dalle Carbonare L, Arlot ME, Chavassieux PM, Roux JP, Portero NR \& Meunier PJ 2001 Comparison of trabecular bone microarchitecture and remodeling in glucocorticoid-induced and postmenopausal osteoporosis. Journal of Bone and Mineral Research 16 97-103. (doi:10.1359/ jbmr.2001.16.1.97)

Eijken M, Hewison M, Cooper MS, de Jong FH, Chiba H, Stewart PM, Uitterlinden AG, Pols HA \& van Leeuwen JP 2005 11ß-Hydroxysteroid dehydrogenase expression and glucocorticoid synthesis are directed by a molecular switch during osteoblast differentiation. Molecular Endocrinology 19 621-631. (doi:10.1210/me.2004-0212)

Hauner H, Schmid P \& Pfeiffer EF 1987 Glucocorticoids and insulin promote the differentiation of human adipocyte precursor cells into fat cells. Journal of Clinical Endocrinology and Metabolism 64 832-835. (doi:10.1210/jcem-64-4-832)

Hofbauer LC, Gori F, Riggs BL, Lacey DL, Dunstan CR, Spelsberg TC \& Khosla S 1999 Stimulation of osteoprotegerin ligand and inhibition of osteoprotegerin production by glucocorticoids in human osteoblastic lineage cells: potential paracrine mechanisms of glucocorticoidinduced osteoporosis. Endocrinology $1404382-4389$.

Hotamisligil GS, Johnson RS, Distel RJ, Ellis R, Papaioannou VE \& Spiegelman BM 1996 Uncoupling of obesity from insulin resistance through a targeted mutation in aP2, the adipocyte fatty acid binding protein. Science 274 1377-1379. (doi:10.1126/science.274.5291.1377)

Ishikawa T, Kamiyama M, Tani-Ishii N, Suzuki H, Ichikawa Y, Hamaguchi Y, Momiyama N \& Shimada H 2001 Inhibition of osteoclast differentiation

http://jme.endocrinology-journals.org DOI: 10.1530/JME-13-0177
() 2014 Society for Endocrinology Printed in Great Britain and bone resorption by cathepsin $\mathrm{K}$ antisense oligonucleotides. Molecular Carcinogenesis 32 84-91. (doi:10.1002/mc.1067)

Kersten JR, Toller WG, Gross ER, Pagel PS \& Warltier DC 2000 Diabetes abolishes ischemic preconditioning: role of glucose, insulin, and osmolality. American Journal of Physiology. Heart and Circulatory Physiology 278 H1218-H1224.

Kim HJ \& Kim SH 2010 Tanshinone IIA enhances BMP-2-stimulated commitment of $\mathrm{C} 2 \mathrm{C} 12$ cells into osteoblasts via p38 activation. Amino Acids 39 1217-1226. (doi:10.1007/s00726-010-0557-8)

Kim K, Lee SH, Ha Kim J, Choi Y \& Kim N 2008 NFATc1 induces osteoclast fusion via up-regulation of Atp6v0d2 and the dendritic cell-specific transmembrane protein (DC-STAMP). Molecular Endocrinology 22 176-185. (doi:10.1210/me.2007-0237)

Kim SH, Bok JH, Lee JH, Kim IH, Kwon SW, Lee GB, Kang SK, Park JS, Jung WH, Kim HY et al. 2012 Synthesis and biological evaluation of cyclic sulfamide derivatives as $11 \beta$-hydroxysteroid dehydrogenase 1 inhibitors. ACS Medicinal Chemistry Letters 3 88-93. (doi:10.1021/ $\mathrm{ml} 200226 \mathrm{x}$ )

Klein RG, Arnaud SB, Gallagher JC, Deluca HF \& Riggs BL 1977 Intestinal calcium absorption in exogenous hypercortisonism. Role of 25-hydroxyvitamin D and corticosteroid dose. Journal of Clinical Investigation 60 253-259. (doi:10.1172/JCI108762)

Kotelevtsev Y, Holmes MC, Burchell A, Houston PM, Schmoll D, Jamieson P, Best R, Brown R, Edwards CR, Seckl JR et al. 1997 11ß-hydroxysteroid dehydrogenase type 1 knockout mice show attenuated glucocorticoidinducible responses and resist hyperglycemia on obesity or stress. PNAS 94 14924-14929. (doi:10.1073/pnas.94.26.14924)

Li G, Peng H, Corsi K, Usas A, Olshanski A \& Huard J 2005 Differential effect of BMP4 on NIH/3T3 and C2C12 cells: implications for endochondral bone formation. Journal of Bone and Mineral Research 20 1611-1623. (doi:10.1359/JBMR.050513)

Masuzaki H, Paterson J, Shinyama H, Morton NM, Mullins JJ, Seckl JR \& Flier JS 2001 A transgenic model of visceral obesity and the metabolic syndrome. Science 294 2166-2170. (doi:10.1126/ science.1066285)

Morton NM, Holmes MC, Fiévet C, Staels B, Tailleux A, Mullins JJ \& Seckl JR 2001 Improved lipid and lipoprotein profile, hepatic insulin sensitivity, and glucose tolerance in 11 $\beta$-hydroxysteroid dehydrogenase type 1 null mice. Journal of Biological Chemistry 276 41293-41300. (doi:10.1074/ jbc.M103676200)

Morton NM, Paterson JM, Masuzaki H, Holmes MC, Staels B, Fievet C, Walker BR, Flier JS, Mullins JJ \& Seckl JR 2004 Novel adipose tissuemediated resistance to diet-induced visceral obesity in 11ß-hydroxysteroid dehydrogenase type 1-deficient mice. Diabetes 53 931-938. (doi:10.2337/diabetes.53.4.931)

Park SY, Choi GH, Choi HI, Ryu J, Jung CY \& Lee W 2005 Calorie restriction improves whole-body glucose disposal and insulin resistance in association with the increased adipocyte-specific GLUT4 expression in Otsuka Long-Evans Tokushima fatty rats. Archives of Biochemistry and Biophysics 436 276-284. (doi:10.1016/j.abb.2005.01.010)

Park JS, Rhee SD, Kang NS, Jung WH, Kim HY, Kim JH, Kang SK, Cheon HG, Ahn JH \& Kim KY 2011 Anti-diabetic and anti-adipogenic effects of a novel selective $11 \beta$-hydroxysteroid dehydrogenase type 1 inhibitor, 2-(3-benzoyl)-4-hydroxy-1,1-dioxo-2H-1,2-benzothiazine-2-yl-1phenylethanone (KR-66344). Biochemical Pharmacology 81 1028-1035. (doi:10.1016/j.bcp.2011.01.020)

Park JS, Rhee SD, Jung WH, Kang NS, Kim HY, Kang SK, Ahn JH \& Kim KY 2012 Anti-diabetic and anti-adipogenic effects of a novel selective $11 \beta$-hydroxysteroid dehydrogenase type 1 inhibitor in the diet-induced obese mice. European Journal of Pharmacology 691 19-27. (doi:10.1016/ j.ejphar.2012.06.024)

Paterson JM, Morton NM, Fievet C, Kenyon CJ, Holmes MC, Staels B, Seckl JR \& Mullins JJ 2004 Metabolic syndrome without obesity: hepatic overexpression of $11 \beta$-hydroxysteroid dehydrogenase type 1 in transgenic mice. PNAS 101 7088-7093. (doi:10.1073/pnas. 0305524101) 
Rosen ED \& MacDougald OA 2006 Adipocyte differentiation from the inside out. Nature Reviews. Molecular Cell Biology 7 885-896. (doi:10.1038/nrm2066)

Rosenstock J, Banarer S, Fonseca VA, Inzucchi SE, Sun W, Yao W, Hollis G, Flores R, Levy R, Williams WV et al. 2010 The 11- $\beta$-hydroxysteroid dehydrogenase type 1 inhibitor INCB13739 improves hyperglycemia in patients with type 2 diabetes inadequately controlled by metformin monotherapy. Diabetes Care 33 1516-1522. (doi:10.2337/dc09-2315)

Sato T, Man ZW, Toide K \& Asahi Y 1997 Plasma membrane content of insulinregulated glucose transporter in skeletal muscle of the male Otsuka Long-Evans Tokushima fatty rat, a model of non-insulindependent diabetes mellitus. FEBS Letters 407 329-332. (doi:10.1016/ S0014-5793(97)00369-4)

Stewart PM \& Krozowski ZS 1999 11ß-Hydroxysteroid dehydrogenase. Vitamins and Hormones 57 249-324.

Tachibe M, Kato R, Sugano S, Kishida T \& Ebihara K 2009 Hydroxypropylated tapioca starch retards the development of insulin resistance in KKAy mice, a type 2 diabetes model, fed a high-fat diet. Journal of Food Science 74 H232-H236. (doi:10.1111/j.1750-3841.2009.01276.x)

Takayanagi H, Kim S, Koga T, Nishina H, Isshiki M, Yoshida H, Saiura A, Isobe M, Yokochi T, Inoue J et al. 2002 Induction and activation of the transcription factor NFATc1 (NFAT2) integrate RANKL signaling for terminal differentiation of osteoclasts. Developmental Cell 3 889-901. (doi:10.1016/S1534-5807(02)00369-6)
Tomlinson JJ, Boudreau A, Wu D, Atlas E \& Haché RJ 2006 Modulation of early human preadipocyte differentiation by glucocorticoids. Endocrinology 147 5284-5293. (doi:10.1210/en.2006-0267)

Wang M 2005 The role of glucocorticoid action in the pathophysiology of the metabolic syndrome. Nutrition and Metabolism 2 3. (doi:10.1186/ 1743-7075-2-3)

Wang ZQ, Ovitt C, Grigoriadis AE, Möhle-Steinlein U, Rüther U \& Wagner EF 1992 Bone and haematopoietic defects in mice lacking c-fos. Nature 360 741-745. (doi:10.1038/360741a0)

Wing RR, Blair EH, Bononi P, Marcus MD, Watanabe R \& Bergman RN 1994 Caloric restriction per se is a significant factor in improvements in glycemic control and insulin sensitivity during weight loss in obese NIDDM patients. Diabetes Care 17 30-36. (doi:10.2337/ diacare.17.1.30)

Wu Z, Bucher NL \& Farmer SR 1996 Induction of peroxisome proliferator-activated receptor gamma during the conversion of $3 \mathrm{~T} 3$ fibroblasts into adipocytes is mediated by $\mathrm{C} / \mathrm{EBP} \beta, \mathrm{C} / \mathrm{EBP} \delta$, and glucocorticoids. Molecular and Cellular Biology 16 4128-4136.

Yamaguchi A, Ishizuya T, Kintou N, Wada Y, Katagiri T, Wozney JM, Rosen V \& Yoshiki S 1996 Effects of BMP-2, BMP-4, and BMP-6 on osteoblastic differentiation of bone marrow-derived stromal cell lines, ST2 and MC3T3-G2/PA6. Biochemical and Biophysical Research Communications 220 366-371. (doi:10.1006/bbrc.1996.0411)

Received in final form 23 December 2013

Accepted 20 January 2014

Accepted Preprint published online 20 January 2014
(C) 2014 Society for Endocrinology Printed in Great Britain
Published by Bioscientifica Ltd. 